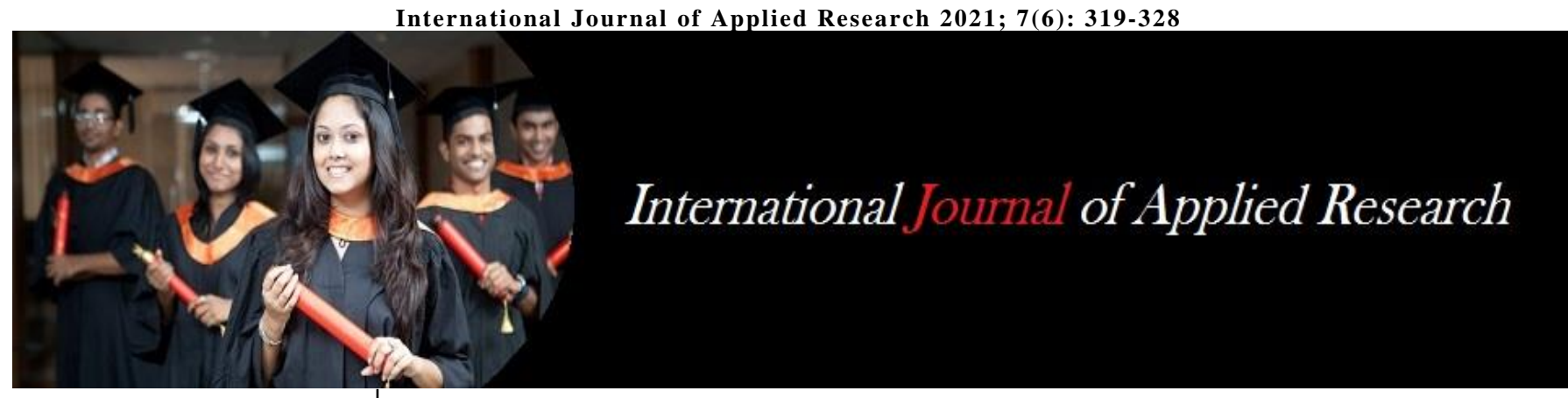

ISSN Print: $2394-7500$

ISSN Online: 2394-5869

Impact Factor: 8.4

IJAR 2021; 7(6): 319-328

www.allresearchjournal.com

Received: 26-04-2021

Accepted: 28-05-2021

Sayeda Ahmed Ahmed Hassan

Department: Accounting

Higher Future Institute for

Specialized Technology Studies

Post office Badr, City Badr,

Cairo, Egypt
Corresponding Author: Sayeda Ahmed Ahmed Hassan Department: Accounting Higher Future Institute for Specialized Technology Studies Post office Badr, City Badr, Cairo, Egypt

\section{The impact of artificial intelligence on the accounting profession in the tourism sector in Egypt}

\author{
Sayeda Ahmed Ahmed Hassan
}

DOI: https://doi.org/10.22271/allresearch.2021.v7.i6e.8716

\begin{abstract}
The research aims to achieve identify the impact of artificial intelligence on the accounting profession. The research reached a set of results, The high level of use of artificial intelligence in companies in the tourism sector from the point of view of the study sample individuals, The high level of technology use in the accounting profession In companies in the tourism sector from the point of view of the study sample individuals, The impact Positive for the level of use of artificial intelligence on the accounting profession from the viewpoint of the study sample.

The research recommends a set of recommendations, The need to work on increasing the use of artificial intelligence applications in the accounting field to benefit from the advantages it enjoys and to obtain solutions to many diverse and complex problems, which will positively affect the decisionmaking process, The necessity for colleges and institutes to teach how to use artificial intelligence applications in the accounting field within the curricula related to the accounting field to qualify a new generation of accountants and professors with the ability to use accounting technological methods and contribute to their development, Institutions and organizations provide programs and courses related to artificial intelligence applications for accountants to increase their capabilities, skills and capabilities in this field, The necessity for financial and management accountants to use artificial intelligence applications to develop their work because of its advantages that help them acquire many skills.
\end{abstract}

Keywords: Artificial Intelligence, Accounting Introduction

\section{Introduction}

The tremendous development in artificial intelligence and the use of technology in support of business inside the facilities and bodies in all its forms, especially in the field of accounting, where the role of artificial intelligence appeared as a strong catalyst for many reasons, the most important of which is the accuracy of accounting information and the abundance of details and records of commercial transactions.

Technology contributes to saving wasted time in entering and analyzing data while ensuring that no potential human error occurs, which contributes to making accounting bodies exploit accounting and analytical capabilities to increase their productivity in another area that serves the success and productivity of companies, which makes most of the business and banking transactions completely focus on the use of AI In all its matters and tasks, especially with the availability of mobile devices and computers with almost all individuals, which facilitated the opportunity for innovation and the availability of conditions for its advancement and the introduction of new possibilities day after day.

The tourism sector is considered one of the sectors in which the use of artificial intelligence in administrative and accounting operations has begun most due to the need for this sector to be very accurate in all dealings, and therefore the research will apply to one of the large companies with multiple branches in this important sector.

\section{Research problem}

Technology has become a fundamental axis of the era, as it is considered a powerful engine for science and industries in different sectors, and because accounting is a prominent sector in supporting financial and administrative decision-making. Therefore, the importance of addressing the relationship of artificial intelligence with technological development and work by documenting the role that technology has added to accounting and financial transactions, as that Information technology contributes significantly to improving and raising the efficiency of the enterprises' activities because they improve the quality of products and reduce the associated costs. 
Information technology also plays an effective role in assisting senior management in making effective decisions and drawing future plans and strategies for the organization. Due to the tremendous development in information and communication technology, the role played by the accountant has changed, as some argue that technology has contributed to giving the accountant new skills to arm with it based on technology and the reality of artificial intelligence intertwined in all the details of business and not only accounting, while some believe that technology has reduced. The importance of the role that the accountant plays in the organization. The problem of the study is that it seeks to identify the level of using artificial intelligence applications in accounting operations within the tourism sector companies, as there is no great interest in the tourism sector companies to pay attention to qualifying accountants working on the use of artificial intelligence applications even though the accounting qualification alone is not sufficient to keep pace with the developments that occurred. In the accounting profession, but accountants must be familiar with cognitive intelligence and technological developments, which contributes to increasing the capabilities of accountants and developing their professional performance.

\section{Importance of studying}

The tourism sector is one of the most important economic sectors in the Egyptian economy, as its contribution to the GDP in 2019 was about $15 \%$.

The tourism sector is considered one of the most tourism sectors that are interested in using artificial intelligence applications due to its great importance in meeting customer needs and its ability to provide extreme accuracy in all transactions that take place within the tourism sector.

The importance of the research is that it aims to identify the level of use of artificial intelligence applications in accounting operations within the tourism sector companies, and it is one of the topics that have not been adequately addressed in scientific studies and research, which indicates that this research is one of the first researches and studies that dealt with this topic, which is an addition Scientific through which it can shed light on this topic, which contributes to encouraging researchers to address this important topic.

\section{Research objectives}

The research aims to achieve a major goal, which is to identify the level of use of artificial intelligence applications in accounting operations within the companies of the tourism sector by achieving a set of sub- objectives, namely:

1. Learn about research terminology and concepts related to the subject of study.

2. Study the level of using artificial intelligence in the Egyptian tourism sector companies.

3. Knowing the level of using accounting technology methods in the Egyptian tourism sector companies.

4. Reaching out to a set of recommendations and proposals through which the best use of artificial intelligence can be achieved in the accounting profession

\section{Research hypotheses}

In order to achieve the objectives of the study, we will assume the following.
First Hypothesis: "There is a statistically significant relationship between artificial intelligence and the accounting profession".

Second Hypothesis: "The high level of use of artificial intelligence in the Egyptian tourism sector companies".

Third Hypothesis: "The high level of using accounting technology methods in the Egyptian tourism sector companies".

\section{Research methodology}

The research uses a set of research methodologies that are commensurate with the research objectives, as it used the descriptive approach to identify the concepts and terms related to the research topic, as well as it will use the standard analytical approach through which a set of standard methods and methods are used to analyze the research data to reach results and recommendations that can be used.

\section{Study population}

The study population includes all companies operating in the tourism sector in Egypt.

\section{Study sample}

As a result of the difficulty of conducting a comprehensive enumeration of the study community, the research will use the sampling method through the use of the control test strategy, which is the components of which are deliberately picked by the exploration due to the accessibility of certain attributes in these people without others, as these people serve the objective of the research, and the research choice came for this. The type is one of the types of samples because it increases the accuracy of the estimates and reduces the size of the error. The research will use the study tool represented in the questionnaire form to obtain the study data from the study sample represented by workers in the financial and accounting departments in 10 companies operating in the tourism sector in Egypt, and these companies have multiple branches all over the Arab Republic of Egypt, and the number of the selected sample is About 120 questionnaires were used in the analysis.

\section{Limits of the study}

- Objective limits: The study aims to identify the impact of using artificial intelligence applications in accounting operations.

- Location limits: One of the companies in the tourism sector in Egypt.

- Time limits: 2020

\section{Theoretical framework \\ First: Research concepts and terms \\ $>$ Artificial intelligence}

It is the electronic systems and programs that collect information in order to carry out the tasks and human roles and is characterized by the fact that it performs accurate analysis of data and aims to enhance and empower human capabilities in a large and very large scale.

\section{$>$ Databases}

It is the repository that contains the data, topics and files organized and interconnected with each other that describe all the processes and events taking place in the organization 
in all their details, and they are organized in the form of files and kept in magnetic computer containers in dependently from the programs that operate and use this data, and the data saved in these rules The raw or primary material from which knowledge and information are extracted. (Khayyam, 2013, pp. 14-17) ${ }^{[9]}$.

\section{Data analysis}

It is a process that includes organizing and arranging available data and information with the aim of summarizing them in a graphic form through which you derive some recommendations and results that will help in making decisions.(Shahbi, 2018, 2) ${ }^{[11]}$.

\section{$>$ Domain database}

A collection of facts and relationships related to a specific topic.

\section{$>$ Database management system}

The programs that operate, control, and manage databases in an efficient and adequate manner. (Hassan, 2015, pp. 61 64).

\section{$>$ accounting administration}

It is an integrated financial system that performs classification and summarization of financial transactions in a simple way through which decisions are made regarding the company's policies and directions in the future. (Siam and Rahleh, 2008, pp. 39-41) ${ }^{[12]}$.

\section{$>$ System Programming}

It is a set of software components such as computer software components, operating systems, financial tables, word and text processing, database programs, communication systems, e-mail programs, internet browsing software, small business enterprise systems, graphs and other programs. (Hammad, 1998, p.37) ${ }^{[6]}$.

The changes brought about by the use of artificial intelligence within the accounting

○ The possibility of accessing the required information through databases by all workers in the accounting sector in the commercial establishment instead of using a paper archive that contains paper papers and accounting books.

- Improving efficiency as analyzes and financial lists depend in large part on the human factor and also on the technology factor, and thus it increases its efficiency and uses the available evidence in a professional manner, (Hammad, 1998, pp. $53-55)^{[6]}$.

- The integrated accuracy because the technological factor rarely results in errors because the operations are repeated codes, and there is no room for human error within those processes. Therefore, we find that the accuracy of using $\mathrm{AI}$ is greater than the accuracy of human use and the accounting transactions resulting from it. (Aghion, 2017, p3) ${ }^{[2]}$.

- Ease of searching and checking available information. (Hassan, 2015, pp. 75-76) ${ }^{[7]}$.

- Better financial protection and control, as technology enables companies to monitor the finances accurately and limit any financial fraud that may occur inside the facilities, as it can detect any defect during commercial transactions, collect invoices and proven papers, and know and monitor any repetition of them (Carlos, 2018, 497) ${ }^{[3]}$.

- Upgrading the decision-making process based on an effective point of view by fully analyzing the available data and assisting in decision- making through it. (Siam and Rahleh, 2008, pp. 49-51) ${ }^{[12]}$.

- AI helps accountants to predict the future and thus make decisions accordingly and suggest appropriate courses of action and solutions to address any deficiency or defect within the appropriate economic performance.

- A comprehensive application of international accounting standards in a completely correct manner, free of errors and keeping pace with the accounting systems for any change that occurs. (Abd al-Nabi, 2017, $91-93)^{[1]}$.

\section{Second: Literature Review}

Study (Hammad, 1989) ${ }^{[5]}$ entitled Artificial Intelligence Methods in Accounting, The use of expert systems in accounting choices decisions, which aimed to identify the methods of artificial intelligence in general and expert systems in particular and how to apply them in the accounting field. The study concluded that there are many expected effects of using expert systems in accounting. These effects include an increase in the creative capacity of accounting, an increase in the level of performance efficiency, an increase in productivity, an increase in the level of competition, and an increase in economic efficiency.

Study (Siam and Rahleh, 2008) ${ }^{[12], ~ e n t i t l e d: ~ " P e r s o n a l ~}$ factors affecting the student from the online accounting university education.

This study was applied in Jordan to the university teaching staff and students, and to measure the extent of awareness of faculty members in accounting departments in Jordanian universities of this importance, in addition to determining the extent of using information technology and the advantages that this use achieves in ensuring the quality of higher education. The two researchers used the descriptive and analytical method, and the study tool was the questionnaire. The study sample consisted of

168 male and female students in the College of Economics and Administrative Sciences. The study found that the awareness of faculty members in the Accounting Department of the importance of using information technology in university teaching is still limited due to obstacles related to faculty members and the available material capabilities

Study (Omoteso 2012) ${ }^{[8]}$ entitled. The application of artificial intelligence in Auditing: Looking back to the future,

The study aimed to apply audit procedures in light of artificial intelligence techniques, and the study reached a set of results, including that audit procedures need to be developed in light of the application of artificial intelligence systems in the modern business environment and that auditors should increase their efforts to find a more effective role in governance and control, and the methods and methods are explained. Through which the expert systems used in auditing can be developed, and it showed the benefits that could increase the efficiency of the audit and the defects that could limit the audit procedures under expert systems, as well as the importance of auditors using 
artificial intelligence in the audit provisions and the benefits of adopting these systems at work Audit and comparison with costs and evaluation of the impact of artificial intelligence on the design of internal control systems.

Study (Kozhakhmet \& Bortsova \& Atymtayeva, 2012) ${ }^{[10]}$ entitled Some Issues of Development of Intelligent System for Information Security Auditing,

The results of the study showed the high cost of implementing expert systems in companies in terms of time and human resources in charge of implementing them, and that automating the audit process through software development can be a good alternative that helps reduce costs. Accelerate the audit process and improve quality by complying with international auditing standards.

Study (Devale \& Kulkarni, 2012) [4] Titled A Review of Expert System in Information System Audit, Which aimed to identify the role of leading technologies in the field of auditing that allow auditors to identify risks and assess the efficiency of control over modern information systems. The study demonstrated the benefits achieved as a result of the transition to The application of computer-based auditing, which can lead to the continuous development and improvement of the audit process by assessing audit risks and assisting in evaluating companies' business, as well as auditing techniques for computer programs such as Expert systems and their use to improve work procedures and reduce errors are still in the early stages From development Study (Khayyam, 2013) ${ }^{[9]}$ the reality of the development of the accounting profession between the professional and technological qualification of accountants in companies operating in the Gaza Strip.

This study investigated the reality of the accounting profession and the reality of technology for accountants working in the corporate sector in the Gaza Strip. The percentage of questionnaires reached 100 questionnaires, and 73 questionnaires were achieved in response to that. The role of the study comes in clarifying all the criteria between the development brought about by AI in the field of accounting and its role in reducing time and maintaining accounting efforts to perform other tasks that add values to customers and also to the financial performance of commercial companies and The study, found that the companies on which the questionnaire was conducted are using technological means in practice for accounting, and this use has a great impact on preparing the financial statements of accountants within companies in an accurate manner and saves time to prepare them.

The study, recommendations that would affect the accounting system in any commercial establishment at this age, including:

o Continuous and permanent development of the grass roots facilities according to the new era technology.

o Setting the framework to evaluate the accounting system with its

o different dimensions

o Developing an illustrated plan for the development of accounting systems in the profession

o Development of continuous research capabilities for creativity inusing AI to serve accounting systems.

Study (Abdel Nabi 2014) ${ }^{[1]}$ the effect of using information technology on the efficiency of modern management accounting methods in industrial companies in the Gaza Strip.
The study aimed to know the level of technology use and its impact on the efficiency of the performance of commercial companies, and a descriptive analytical approach is followed to analyze performance in the method of comprehensive quality management, the target cost and the impact of technology in general on overall performance.

The study concluded that it is necessary to highlight the importance of information technology in management accounting methods, by activating it in conferences, lectures, seminars and training courses, and the necessity to keep abreast of developments and pursue modern systems, especially in the areas of modern management accounting methods, and to train those in charge and workers on them by raising their competence, and encouraging Industrial companies in the Gaza Strip to train their cadres to use programs and applications of modern electronic management accounting methods.

\section{Applied Framework \\ $>$ Study tool}

The examination depended on leading individual meetings, yet they were coordinated through surveys for interviews. These surveys were set up by characterizing the inquiries ahead of time in a coordinated constantly way as a poll structure with the respondents 'discourse and conversation in the central matters of the examination subject to acquire data, assessments and practices that can be uncovered from because of these meetings.

The specialist arranged the survey and decided its tomahawks and states, and the analyst used to fabricate and set up the poll with the hypothetical structure of the examination, past investigations identified with the subject of the examination, and the poll included two tomahawks (the hub of the degree of utilization of man-made consciousness, the hub of the degree of innovation use in the bookkeeping calling) and the quantity of poll phrases arrived at 40 The five-point Likert scale comprising of unequivocally concur (5), concur (4), unbiased (3), dissent (2), emphatically deviate (1) was utilized in addressing the inquiries of the examination tomahawks.

\section{$>$ Validate the examination apparatus}

The current examination was embraced to ascertain the legitimacy of surveys on the accompanying strategies:

A. Arbitration trustworthiness or evident genuineness The specialist introduced the survey in its underlying structure to (5) of the appointed authorities, to convey an evaluation on their agree to the hatchets of the survey terms and to know their speculations and insights about the sensibility of the survey phrases for the subjects and subject of the assessment, and the level of clearness and precision of calculating the articulations and their etymological uprightness, Delete, change and add expresses, and considering this the surveys arrangement was reformulated in its last construction.

B. Self-validity: In solicitation to assemble the certification of the authenticity of the survey, the coefficient of sufficiency of the overview was resolved, and subsequently the self-dependability coefficient was resolved through the going with condition Coefficient of trustworthiness = coefficient of strength. 
Legitimacy of the poll $=0.839=0.916$

That is, the self-legitimacy coefficient of the survey arrived at a degree in overabundance of 0.90 , and this degree is high, and shows that the poll has a serious level of genuineness, and is substantial for application to the people of the investigation test

\section{Constructive honesty}

The structural validity of the questionnaire was verified by distributing the questionnaire form to a simple random sample (10 individuals), to determine the extent of internal homogeneity of the study tool, by determining the correlation coefficients between each phrase and the degree of the phrase contained in the axis to which the phrase belongs where the results came as follows:

\section{The first axis: the level of use of artificial intelligence}

Table 1: Correlation coefficients between the score for each phrase and the total score for the first axis

\begin{tabular}{|c|c|c|}
\hline N. & Phrase & $\begin{array}{l}\text { Correlation } \\
\text { coefficient }\end{array}$ \\
\hline 1 & Artificial intelligence contributes to developing solutions to various problems of the organization & $* * 0.736$ \\
\hline 2 & Artificial intelligence is designed to handle accounting events and processes & $* * 0.614$ \\
\hline 3 & Artificial intelligence is used to improve decision-making in the enterprise through the information stored in databases & $* * 0.723$ \\
\hline 4 & $\begin{array}{l}\text { Artificial intelligence helps in gaining knowledge from the reality of the databases stored by the systems in the areas that support } \\
\text { the capabilities of the higher management in the organization }\end{array}$ & $* * 0.742$ \\
\hline 5 & Artificial intelligence helps managers in the planning and decision-making process of various organizations in the organization & $* * 0.739$ \\
\hline 6 & Artificial intelligence allows symbolic knowledge to be clearly represented, such as graphs, semantic networks, and texts & $* * 0.815$ \\
\hline 7 & Symbolic and inferential knowledge of an organization has the power to extrapolate information from complex data & $* * 0.739$ \\
\hline 8 & Artificial intelligence is characterized by the ability to adapt to its cognitive environment within the organization & $* * 0.615$ \\
\hline 9 & Artificial intelligence allows knowledge to be stored quickly and adequately. & $* * 0.762$ \\
\hline 10 & Knowledge and inferences are represented according to criteria defined by the organization & $* * 0.753$ \\
\hline 11 & Knowledge and inferences are kept securely to protect them from any manipulation. & $* * 0.728$ \\
\hline 12 & The enterprise system can automatically handle the problems it may encounter. & $* * 0.733$ \\
\hline 13 & Systems within the same organization happen periodically and automatically. & $* * 0.782$ \\
\hline 14 & Enterprise systems are linked to each other in an integrated and interactive manner. & $* * 0.746$ \\
\hline 15 & Enterprise systems handle logical and programmatic accounting errors. & $* * 0.717$ \\
\hline 16 & Enterprise systems have the ability to automatically detect tampering with them. & $* * 0.629$ \\
\hline 17 & $\begin{array}{l}\text { The organization's accounting system maintains a copy of the data automatically in the event of a sudden failure in the } \\
\text { organization's network }\end{array}$ & $* * 0.733$ \\
\hline 18 & Specialized companies carry out periodic maintenance of the institution's artificial intelligence devices & $* * 0.672$ \\
\hline 19 & Specialized companies regularly update the programs related to artificial intelligence at the institution & $* * 0.645$ \\
\hline 20 & The devices and equipment currently used by the institution are compatible with artificial intelligence systems & $* * 0.726$ \\
\hline
\end{tabular}

**Genuinely huge at the degree of importance $(\alpha=0.01)$

The second axis: The level of technology use in the accounting profession

Table 2: Correlation coefficients between the score for each phrase and the total score for the second axis

\begin{tabular}{|c|c|c|}
\hline N. & 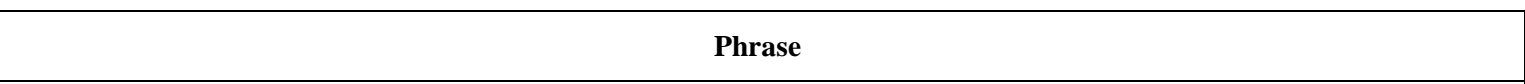 & $\begin{array}{c}\text { Correlation } \\
\text { coefficient }\end{array}$ \\
\hline 1 & The outputs of the sub-accounting information systems are characterized by quality and efficiency & $* * 0.692$ \\
\hline 2 & The subsystems that make up the accounting information system are characterized by interdependence on each other & $* * 0.759$ \\
\hline 3 & Deleting any subsystem of accounting information systems leads to distorting the accounting information system as a whole & $* * 0.679$ \\
\hline 4 & Databases are used by subsystems without having to be repeatedly entered & $* * 0.717$ \\
\hline 5 & Decision support systems are distinguished by their dependence on information derived from more than one subsystem & $* * 0.745$ \\
\hline 6 & An accounting information system consists of several subsystems linked together to perform specific functions & $* * 0.879$ \\
\hline 7 & The goals of the accounting information system are related to the goals of the enterprise as a whole & $* * 0.843$ \\
\hline 8 & Accounting information systems are associated with the financial and administrative systems in the organization & $* * 0.821$ \\
\hline 9 & Accounting information systems help senior management to make accounting reviews & $* * 0.795$ \\
\hline 10 & The accounting information systems used ensure that neutral financial reports are obtained & $* * 0.742$ \\
\hline 11 & The listed accounting information contained in the financial reports issued by the accounting information systems is objective & $* * 0.807$ \\
\hline 12 & $\begin{array}{c}\text { The information contained in the financial reports issued by the accounting information system is characterized by the ability to } \\
\text { verify its correctness }\end{array}$ & $* * 0.726$ \\
\hline 13 & The accounting information system provides a set of controls to ensure the correctness and integrity of data processing & $* * 0.712$ \\
\hline 14 & The accounting information systems provided to the institution with disclosures and clarifications on financial reporting items & $* * 0.697$ \\
\hline 15 & Accounting information is presented in the form of reports and lists in accordance with the accounting requirements & $* * 0.753$ \\
\hline 16 & The enterprise information systems contribute to providing annual and interim financial reports. & $* * 0.729$ \\
\hline 17 & The accounting standards applicable to the preparation of the financial statements shall be taken into consideration & $* * 0.682$ \\
\hline 18 & The accounting information contained in the financial reports and the accompanying disclosures is transparent & $* * 0.736$ \\
\hline 19 & The accounting system used contributes to achieving the organization's goals & $* * 0.664$ \\
\hline 20 & The accounting system works to raise the efficiency of the organization's performance & 0.747 \\
\hline
\end{tabular}

Measurably huge at the degree of importance $(\alpha=0.01)$ From the past tables, we notice that all connection coefficients for all survey things were genuinely huge at the degree of importance $\alpha=(0.01)$, and this means that the tool has structural validity and is valid for the purposes of the study. Correlation coefficients ranged between $(0.879)$ in its upper limit before term 6 in the second axis and (0.614) in its lower limit, in front of expression 2 in the first axis.

\section{The security of the examination instrument}


Table 3: Stability coefficient of the overview hub

\begin{tabular}{|c|c|c|}
\hline Axis & $\begin{array}{c}\text { Alpha } \\
\text { Kornbach }\end{array}$ & $\begin{array}{c}\text { Number of } \\
\text { elements }\end{array}$ \\
\hline $\begin{array}{c}\text { The level of use of artificial } \\
\text { intelligence }\end{array}$ & 0.833 & 20 \\
\hline $\begin{array}{c}\text { The level of technology use in the } \\
\text { accounting profession }\end{array}$ & 0.849 & 20 \\
\hline Total questionnaire & 0.839 & 40 \\
\hline
\end{tabular}

Source: Results of the statistical analysis

The Alpha Kornbach coefficient was resolved for the parts of the hatchets of the survey construction and we notice from these results that the assessment of the strength factor Alpha for the hatchets of the review structure is more unmistakable than 0.79 which is a strong robustness factor that avows the authenticity and association of the segments of the hatchets of the overview structure, similarly as exhibits the security of the study when all is said in done.

1. Statistical strategies for information investigation

2. Arithmetic mean

3. Relative weight

$$
(5 \mathrm{X} 1+4 \mathrm{X} 2+3 \mathrm{X} 3+2 \mathrm{X} 4+1 \mathrm{X} 5) / 5 \mathrm{~N}
$$

Where:

$\mathrm{K} 1$ = number of emphatically concur

$\mathrm{K} 2$ = number of concur

$\mathrm{K} 3$ = number of nonpartisan
$\mathrm{K} 4$ = number of conflict

$\mathrm{K} 5$ = number of emphatically clash

$\mathrm{N}=$ number of study test

Alpha-Kornbach test: It is a proportion of the strength of the test.

Correlation coefficient test: which is utilized to distinguish the measurable meaning of connections among's factors and to guarantee the legitimacy of the inward consistency of the instrument by discovering a Pearson relationship coefficient between every vertebra and the general score of the vertebrae.

\section{Analysis of the survey}

First: Characteristics of the investigation test

\section{Gender}

The example of the investigation consists 78 male people, 65 $\%$ while 42 female individuals came to $21.67 \%$.

Table 4: Distribution of the investigation test as indicated by sex

\begin{tabular}{|c|c|c|}
\hline Categories & $\mathbf{N}$ & \% \\
\hline Male & 78 & 65 \\
\hline female & 42 & 35 \\
\hline Total & 120 & 100 \\
\hline
\end{tabular}

Source: Study sample data

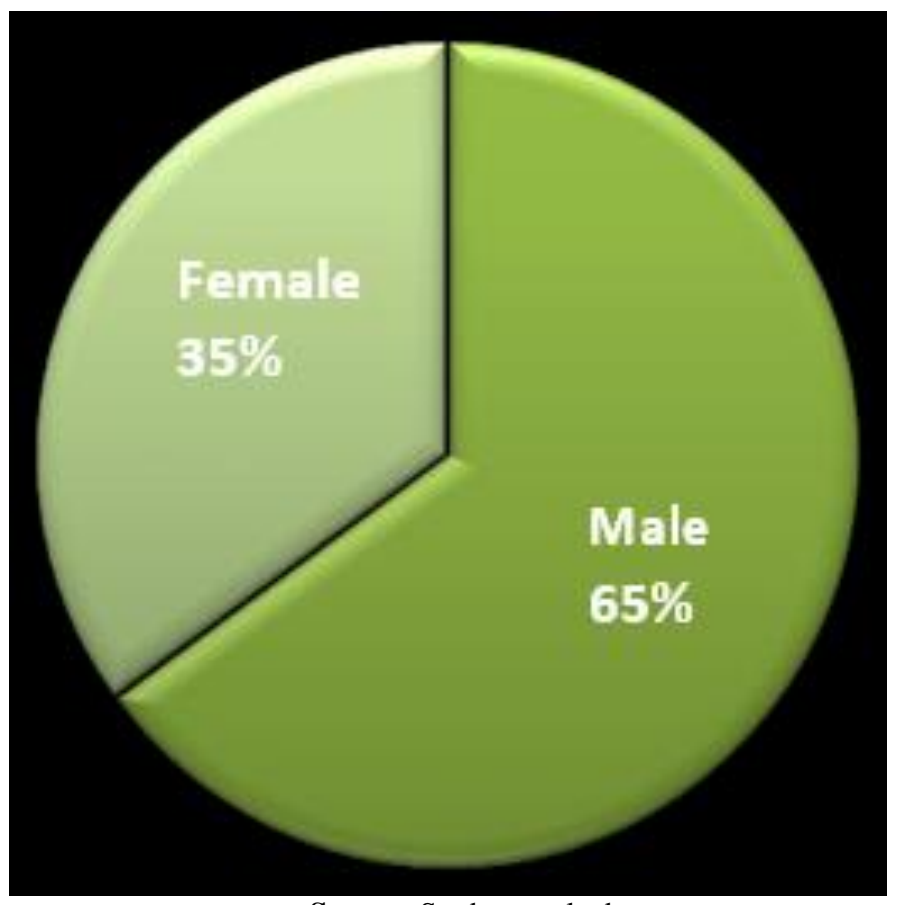

Source: Study sample data

Fig 1: Distribution of the study sample according to gender

Age

The investigation test was separated by the age into 4 classifications. The level of the examination test people under 25 years was $11.67 \%$ of the investigation test, while the level of the examination test people matured between 26-35 years was $48.33 \%$ of the examination test, while the level of the investigation test people whose ages were From $36-45$ years old $25 \%$ of the examination test, and the level of study test people who are 46 years of age and more than is $15 \%$ of the investigation test.
Table 5: Distribution of the study sample according to age

\begin{tabular}{|c|c|c|}
\hline Categories & $\mathbf{N}$ & $\mathbf{\%}$ \\
\hline Less than 25 years & 14 & 11.67 \\
\hline From 26 - 35 years & 58 & 48.33 \\
\hline From 36 - 45 years & 30 & 25.00 \\
\hline More than 46 years & 18 & 15.00 \\
\hline Total & 120 & 100 \\
\hline
\end{tabular}

Source: Study sample data 


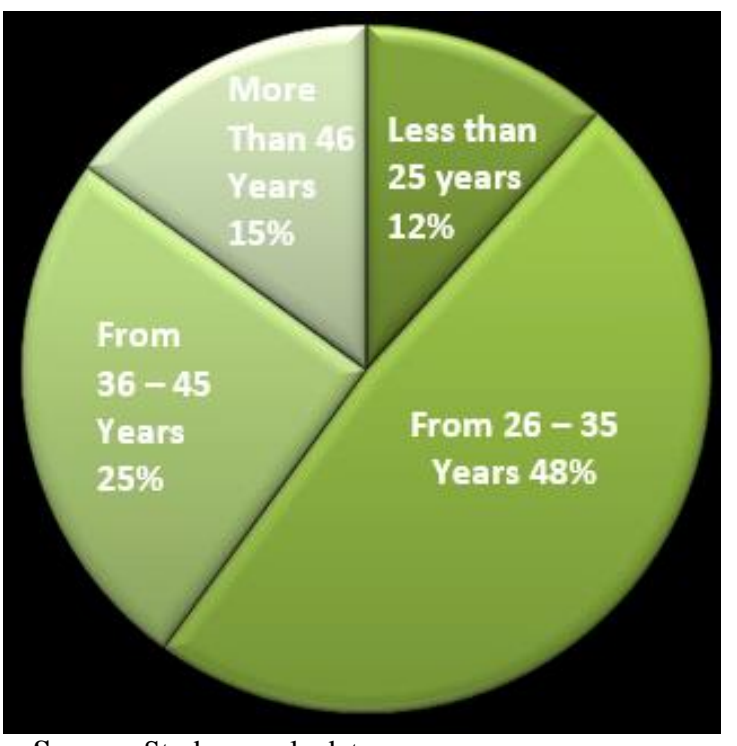

Source: Study sample data

Fig 2: Distribution of the study sample according to age

\section{Years of involvement with the organization}

The examination test was partitioned by the quantity of long periods of involvement with the organization into 4 classes. The level of study test people who have insight of 5 years or less is $23.33 \%$ of the examination test, while the level of study test people with experience of 6-10 years is $36.67 \%$ of the investigation test, while the level of people The examination test whose experience arrives at $11-15$ years is $26.67 \%$ of the investigation test, while the level of the investigation test people whose experience arrives at 16 years or more is $13.33 \%$ of the examination test.
Table 6: Distribution of the study sample according to Years of experience in the company

\begin{tabular}{|c|c|c|}
\hline Categories & $\mathbf{N}$ & $\mathbf{\%}$ \\
\hline 5 years or less & 28 & 23.33 \\
\hline 6-10 years & 44 & 36.67 \\
\hline From 11 to 15 years old & 32 & 26.67 \\
\hline 16 years and over & 16 & 13.33 \\
\hline Total & 120 & 100 \\
\hline
\end{tabular}

Source: Study sample data

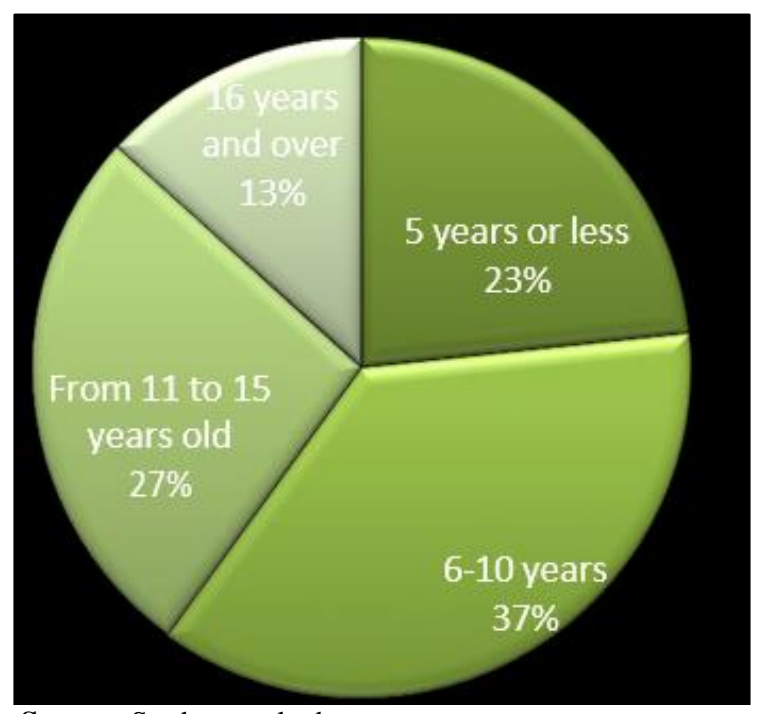

Source: Study sample data

Fig 3: Distribution of the study sample according to Years of experience in the company

Second: The axes of study

The first axis (the level of use of artificial intelligence)

Table 7: Phrases of the first axis

\begin{tabular}{|c|c|c|c|c|c|c|c|c|}
\hline N. & Phrase & $\begin{array}{l}\text { Strongly } \\
\text { agree \% }\end{array}$ & Agree \% & Neutral \% & Disagree \% & $\begin{array}{c}\text { Strongly } \\
\text { disagree \% }\end{array}$ & Mean & Relative weight \\
\hline 1 & $\begin{array}{c}\text { Artificial intelligence contributes to developing solutions to } \\
\text { various problems of the organization }\end{array}$ & 36.67 & 28.33 & 20 & 11.67 & 3.33 & 3.833 & 0.767 \\
\hline 2 & $\begin{array}{c}\text { Artificial intelligence is designed to handle accounting events } \\
\text { and processes }\end{array}$ & 30 & 37.29 & 20.34 & 10 & 1.67 & 3.783 & 0.757 \\
\hline 3 & $\begin{array}{l}\text { Artificial intelligence is used to improve decision-making in the } \\
\text { enterprise through the information stored in databases }\end{array}$ & 30 & 40 & 20 & 6.67 & 3.33 & 3.867 & 0.773 \\
\hline 4 & Artificial intelligence helps in gaining knowledge from the & 28.33 & 34.48 & 22.41 & 10 & 3.33 & 3.633 & 0.727 \\
\hline \multicolumn{9}{|c|}{ Reality of the databases stored by the systems in the areas that support the capabilities of the higher management in the organization } \\
\hline 5 & $\begin{array}{c}\text { Artificial intelligence helps managers in the planning and } \\
\text { decision-making process of various organizations in the } \\
\text { organization }\end{array}$ & 33.33 & 35 & 21.67 & 8.33 & 1.67 & 3.9 & 0.780 \\
\hline 6 & $\begin{array}{l}\text { Artificial intelligence allows symbolic knowledge to be clearly } \\
\text { represented, such as graphs, semantic networks, and texts }\end{array}$ & 30 & 31.67 & 23.33 & 11.67 & 3.33 & 3.733 & 0.747 \\
\hline 7 & $\begin{array}{c}\text { Symbolic and inferential knowledge of an organization has the } \\
\text { power to extrapolate information from complex data. }\end{array}$ & 28.33 & 40 & 21.67 & 6.67 & 3.33 & 3.833 & 0.767 \\
\hline 8 & $\begin{array}{l}\text { Artificial intelligence is characterized by the ability to adapt to } \\
\text { its cognitive environment within the organization }\end{array}$ & 33.33 & 37.7 & 18.03 & 6.67 & 5 & 3.933 & 0.787 \\
\hline 9 & $\begin{array}{l}\text { Artificial intelligence allows knowledge to be stored quickly } \\
\text { and adequately. }\end{array}$ & 31.67 & 31.67 & 21.67 & 6.67 & 8.33 & 3.717 & 0.743 \\
\hline 10 & $\begin{array}{c}\text { Knowledge and inferences are represented according to criteria } \\
\text { defined by the organization }\end{array}$ & 36.67 & 33.33 & 23.33 & 3.33 & 3.33 & 3.967 & 0.793 \\
\hline 11 & $\begin{array}{c}\begin{array}{c}\text { Knowledge and inferences are kept securely to protect them } \\
\text { from any manipulation. }\end{array}\end{array}$ & 35 & 31.67 & 18.33 & 6.67 & 8.33 & 3.783 & 0.757 \\
\hline 12 & $\begin{array}{l}\text { The enterprise system can automatically handle the problems it } \\
\text { may encounter }\end{array}$ & 35 & 30 & 16.67 & 8.33 & 10 & 3.717 & 0.743 \\
\hline 13 & $\begin{array}{c}\text { Systems within the same organization happen periodically and } \\
\text { automatically }\end{array}$ & 33.33 & 33.33 & 18.33 & 6.67 & 8.33 & 3.767 & 0.753 \\
\hline 14 & $\begin{array}{c}\text { Enterprise systems are linked to each other in an integrated and } \\
\text { interactive manner }\end{array}$ & 31.67 & 31.67 & 20 & 8.33 & 8.33 & 3.7 & 0.740 \\
\hline 15 & $\begin{array}{c}\text { Enterprise systems handle logical and programmatic accounting } \\
\text { errors }\end{array}$ & 30 & 33.33 & 21.67 & 5 & 10 & 3.683 & 0.737 \\
\hline 16 & Enterprise systems have the ability to automatically detect & 35 & 31.67 & 18.33 & 6.67 & 8.33 & 3.783 & 0.757 \\
\hline
\end{tabular}




\begin{tabular}{|c|c|c|c|c|c|c|c|c|}
\hline & tampering with them & & & & & & & \\
\hline 17 & $\begin{array}{c}\text { The organization's accounting system maintains a copy of the } \\
\text { data automatically in the event of a sudden failure in the } \\
\text { organization's network }\end{array}$ & 33.33 & 35 & 21.67 & 8.33 & 1.67 & 3.9 & 0.780 \\
\hline 19 & $\begin{array}{c}\text { Specialized companies regularly update the programs related to } \\
\text { artificial intelligence at the institution }\end{array}$ & 35 & 30 & 16.67 & 8.33 & 10 & 3.717 & 0.743 \\
\hline 20 & $\begin{array}{l}\text { The devices and equipment currently used by the institution are } \\
\text { compatible with artificial intelligence systems }\end{array}$ & 33.33 & 33.33 & 18.33 & 6.67 & 8.33 & 3.767 & 0.753 \\
\hline
\end{tabular}

Source: Study sample data

When masterminding the pivot (the degree of utilization of man-made consciousness) hub table (7) as far as the level of relative significance (the biggest relative weight esteem) according to the perspective of the examination test, it is uncovered that (Knowledge and deductions are addressed by models characterized by the association) is the main expression of the hub with weight Relative added up to 0.793and Phrase was (Artificial insight helps in acquiring information from the truth of the data sets put away by the frameworks in the spaces that help the capacities of the greater administration in the association) It is the most unsignificant expression of the hub with weight Relative added up to 0.727 .

Table 8: The levels of the first axis

\begin{tabular}{|c|c|}
\hline level & \% \\
\hline Low & 14.17 \\
\hline Average & 19.67 \\
\hline High & 66.16 \\
\hline Total & 100 \\
\hline
\end{tabular}

Source: Study sample data

It is clear from the table (8) that the level of use of artificial intelligence axis has been divided into 3 levels (high medium - low), and it was found that $66.16 \%$ of the sample, the focus of the study, is in the high level, while $19.67 \%$ is in the middle level, while the low level consists of $14.17 \%$.
From the sample, which indicates the high level of use of artificial intelligence from the point of view of the study sample individuals, which shows the validity of the assumption of the second study.

\section{The second axis (the level of technology use in the accounting profession)}

Table 9: Phrases of the second axis

\begin{tabular}{|c|c|c|c|c|c|c|c|c|}
\hline N. & Phrase & Strongly agree \% & Agree \% & Neutral \% & Disagree $\%$ & \begin{tabular}{|c|} 
Strongly \\
disagree \%
\end{tabular} & Mean & $\begin{array}{c}\text { Relative } \\
\text { weight }\end{array}$ \\
\hline 1 & $\begin{array}{c}\text { The outputs of the sub-accounting } \\
\text { Information systems are characterized by } \\
\text { quality and efficiency }\end{array}$ & 31.67 & 28.33 & 23.33 & 10 & 6.67 & 3.683 & 0.737 \\
\hline 2 & $\begin{array}{l}\text { The subsystems that make up the accounting } \\
\text { information system }\end{array}$ & 30 & 30 & 25 & 11.67 & 3.33 & $\begin{array}{c}3.71 \\
7\end{array}$ & 0.743 \\
\hline
\end{tabular}

Continue.....

\begin{tabular}{|c|c|c|c|c|c|c|c|c|}
\hline $\mathrm{N}$ & \multicolumn{8}{|c|}{ Characterized by interdependence on each other } \\
\hline 3 & $\begin{array}{l}\text { Deleting any subsystem of accounting information systems leads to } \\
\text { distorting the accounting information system as a whole }\end{array}$ & 33.33 & 28.33 & 21.67 & 6.67 & 10 & 3.683 & 0.737 \\
\hline 4 & Databases are used by Subsystems without having to be repeatedly Entered & 31.67 & 26.67 & 26.67 & 5 & 10 & 3.65 & 0.730 \\
\hline 5 & $\begin{array}{c}\text { Decision support systems are distinguished by their dependence on } \\
\text { information derived from more than one subsystem }\end{array}$ & 35 & 31.67 & 25 & 5 & 3.33 & 3.9 & 0.780 \\
\hline 6 & $\begin{array}{c}\text { An accounting information system consists of several subsystems linked } \\
\text { together to perform specific functions }\end{array}$ & 36.67 & 30 & 23.33 & 6.67 & 3.33 & 3.9 & 0.780 \\
\hline 7 & $\begin{array}{l}\text { The goals of the accounting information system are related to the goals of } \\
\text { the enterprise as a whole }\end{array}$ & 38.33 & 28.33 & 21.67 & 5 & 6.67 & 3.867 & 0.773 \\
\hline 8 & Accounting information systems & 31.67 & 33.33 & 26.67 & 5 & 3.33 & 3.85 & 0.770 \\
\hline
\end{tabular}


Continue.....

\begin{tabular}{|c|c|c|c|c|c|c|c|c|}
\hline \multicolumn{8}{|c|}{ Associated with the financial and administrative systems in the organization } \\
\hline 9 & Accounting information system help senior management to make accounting reviews & 36.67 & 28.33 & 20 & 6.67 & 8.33 & 3.783 & 0.757 \\
\hline 10 & $\begin{array}{c}\text { The accounting information systems used Ensure that neutral financial reports are } \\
\text { obtained }\end{array}$ & 30 & 35 & 21.67 & 5 & 8.33 & 3.733 & 0.747 \\
\hline 11 & $\begin{array}{c}\text { The listed accounting information contained in the financial reports issued by the } \\
\text { accounting information systems is objective }\end{array}$ & 41.67 & 30 & 23.33 & 3.33 & 1.67 & 4.067 & 0.813 \\
\hline 12 & $\begin{array}{c}\text { The information contained in the financial reports issued by the Accounting information } \\
\text { system is Characterized by the ability to verify its correctness }\end{array}$ & 40 & 28.33 & 21.67 & 6.67 & 3.33 & 3.95 & 0.790 \\
\hline 13 & $\begin{array}{c}\text { The accounting information system provides a set of controls to ensure the correctness } \\
\text { and integrity of data processing }\end{array}$ & 36.67 & 26.67 & 23.33 & 3.33 & 10 & 3.767 & 0.753 \\
\hline
\end{tabular}

Continue.....

\begin{tabular}{|c|c|c|c|c|c|c|c|c|}
\hline 14 & $\begin{array}{c}\text { The accounting information systems provided to the institution with disclosures and } \\
\text { clarifications on financial reporting items }\end{array}$ & 38.33 & 31.67 & 20 & 5 & 5 & 3.933 & 0.787 \\
\hline 15 & ccounting information is nresented in the form of renorts and lists in Accordance wit & 38.33 & 28.33 & 21.67 & 5 & 6.67 & 3.867 & 0.773 \\
\hline 16 & 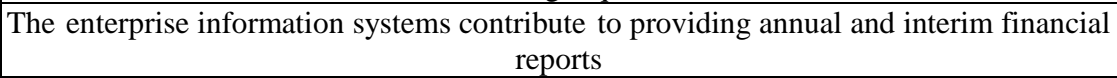 & 31.67 & 28.33 & 23.33 & 10 & 6.67 & 3.683 & 0.737 \\
\hline 17 & $\begin{array}{l}\text { The accounting standards applicable to the } \\
\text { be taken int }\end{array}$ & 30 & 30 & 25 & 11.67 & 3.33 & 3.717 & 0.743 \\
\hline 18 & $\begin{array}{r}\text { The accounting information contained in } \mathrm{t} \\
\text { disclosures } \mathrm{i}\end{array}$ & 33.33 & 28.33 & 21.67 & 6.67 & 10 & 3.683 & 0.737 \\
\hline 19 & The accounting system used contributes to achieving the organization's goals & 38.33 & 28.33 & 21.67 & 5 & 6.67 & 3.867 & 0.773 \\
\hline 20 & The accounting system works to raise the efficiency of the organization's performance & 35 & 31.67 & 25 & 5 & 3.33 & 3.9 & 0.780 \\
\hline
\end{tabular}

Source: Study sample data

When arranging the axis (the level of technology use in the accounting profession) pivot table (9) as far as the level of relative significance (the biggest relative weight esteem) according to the perspective of the investigation test, it is uncovered that (The recorded bookkeeping data contained in the monetary reports gave by the bookkeeping data frameworks is unbiased) is the main expression of the hub with weight Relative added up to 0.813 and Phrase was (Databases are utilized by subsystems without being over and again entered) It is the most un- significant expression of the hub with weight Relative added up to 0.730 .

Table 10: the levels of the subsequent pivot

\begin{tabular}{|c|c|}
\hline Level & \% \\
\hline Low & 12.45 \\
\hline Average & 17.33 \\
\hline High & 70.22 \\
\hline Total & 100 \\
\hline
\end{tabular}

Source: Study sample data

It is obvious from the table (10) that the degree of innovation use in the bookkeeping calling hub has been separated into 3 levels (high-medium-low) and it was tracked down that $70.22 \%$ of the example, the focal point of the investigation, is in the undeniable level, while $17.33 \%$ is in the center level, while the low level comprises of $12.45 \%$ of The example, which shows the significant degree of innovation use in the bookkeeping calling according to the perspective of the examination test people, Which shows the validity of the hypothesis of the third study.

\section{The relationship between artificial intelligence and the accounting profession}

The research assumes that there is a statistically significant relationship between artificial intelligence and the accounting profession, and when performing a statistical test to find out the validity of the hypothesis, the researcher used the method of correlation coefficients, and the results were as follows

Table 11: The relationship between artificial intelligence and the accounting profession

\begin{tabular}{|c|c|}
\hline Variable & Accounting profession \\
\hline Level of artificial intelligence & $* * 0.797$ \\
\hline
\end{tabular}

$* *$ Statistically significant at the level of significance $(\alpha=0.01)$

It is evident from the previous table that there is a direct correlation relationship with statistical significance between the variable of the level of the use of artificial intelligence and the variable of the accounting profession at the level of significance 0.01 , which shows the validity of the assumption of the first study and shows that the higher the level of the use of artificial intelligence, the higher the level of efficiency and effectiveness of the accounting profession, which shows the existence of an impact Positive for the level of use of artificial intelligence on the accounting profession from the viewpoint of the study sample.

\section{Results}

\section{The research reached a set of results namely}

- The high level of use of artificial intelligence in companies in the tourism sector from the point of view of the study sample individuals.

- The high level of technology use in the accounting profession. In companies in the tourism sector from the point of view of the study sample individuals.

- The impact Positive for the level of use of artificial intelligence on the accounting profession from the viewpoint of the study sample.

\section{Recommendations}

- The research recommends a set of recommendations, namely: 
- The need to work on increasing the use of artificial intelligence applications in the accounting field to benefit more from the advantages it enjoys and to obtain solutions to many varied and complex problems, which will positively affect the decision-making process.

- The necessity for colleges and institutes to teach how to use artificial intelligence applications in the accounting field within the curricula related to the accounting field to qualify a new generation of accountants and professors with the ability to use accounting technological methods and contribute to their development.

- Institutions and organizations provide programs and courses related to artificial intelligence applications to accountants to increase their capabilities, skills and capabilities in this field.

- The need for financial and administrative accountants to use artificial intelligence applications to develop their work in a greater manner than is currently being applied because of its advantages that help them acquire many skills.

\section{References}

1. Abd al-Nabi, Siraj Talaat. The effect of using information technology on the efficiency of modern management accounting methods in industrial companies in the Gaza Strip - Scientific Research and Postgraduate Studies, Islamic University - Gaza, 2017.

2. Aghion P, Jones BF, Jones CI. Artificial Intelligence and Economic Growth (No. w23928). NationalBureau of Economic Research, 2017.

3. Carlos RC, Kahn CE, Halaby S. Data science: big data, machine learning, and artificial intelligence. Journal of the American College of Radiology, 2018;15:3.

4. Devale AB, Kulkarni RV. A Review of expert system in information system audit", (IJCSIT) International Journal of computer science and information technologies, engineering, WCE, London, U.K. 2012;2:3(5).

5. Hammad Ahmed Hany. Artificial intelligence methods in accounting, The use of expert systems in accounting choices decisions, The Egyptian Journal of Business Studies 1989;13:2.

6. Hammad Ahmed Hany. Methods of artificial intelligence in accounting, the use of expert systems in accounting choices decisions - The Egyptian Journal of Commercial Studies - Egypt, 1998.

7. Hassan, Mahmoud. Information Technology and its role in developing strategic performance, College of Administration and Economics - University of Diyala Iraq, 2015.

8. Kamil Omoteso. The application of artificial intelligence in auditing: Looking back to the future", Expert systems with applications, Elsevier Inc. 2012;39:8490-8495.

9. Khayyam, Ahmad. The accounting profession between the professional and technological qualification of accountants in companies operating in the Gaza Strip, Faculty of Commerce - Department of Accounting and Finance, Islamic University - Gaza, 2013.

10. Kozhakhmet Kanat T, Bortsova Gerda K, Atymtayeva Lyazzat B. Some Issues of development of intelligent system for information security auditing", Proceedings of the World Congress on, 2012".

11. Shahbi Samia, Krouche Spatial. Artificial intelligence between reality and expectations, Technical and field study, international forum (Artificial Intelligence - A New challenge to law) November 26-27, Algeria, 2018.

12. Siam, Mahmoud, Rahhala Hani. Personal factors affecting the student from the electronic accounting university education, Faculty of Economics and Administration, Balqa University, Jordan, 2008. 